\title{
Red Tilapia Broodstocks and Larval Production Under Different Water Salinities Without Acclimation
}

\author{
Ghada R Sallam ${ }^{1}$, Walied A Fayed ${ }^{2 *}$, Mohamed A El-Absawy ${ }^{3}$, Hadir A Aly ${ }^{1}$ and Zeinab A El-Greisy ${ }^{3}$
}

${ }^{1}$ Aquaculture Division, Fish Rearing laboratory, National Institute of Oceanography and Fisheries, Alexandria Branch, Alexandria, Egypt

${ }^{2}$ Department of Animal and Fish Production, Faculty of Agriculture (Saba Basha), Alexandria University, Alexandria, Egypt

${ }^{3}$ Aquaculture Division, Fish Reproduction laboratory, National Institute of Oceanography and Fisheries, Alexandria Branch, Alexandria, Egypt

\begin{abstract}
The direct transfer of fish to marine water without acclimation is considered critical on survival rate of fish Florida red Tilapia, Oreochromis sp., was introduced to four salinity levels $(9 \%, 18 \%, 24 \%$ and $36 \%$ ) and a contro freshwater treatment in pre-spawning period to investigate the tolerance of the offspring to direct transfer to marine water without acclimation. Fish were stocked at a rate of $25 / \mathrm{m}^{3}$ with initial body weight of $29.4 \pm 0.12 \mathrm{~g}$ for six weeks as acclimation period. Broodstocks after acclimation were then stocked at $5 / \mathrm{m}^{3}$ and fed to satiation with $25 \%$ crude protein commercial diet for 24 weeks as spawning period. Offsprings survival and growth were compared for their tolerance to three salinity levels $(9 \%, 18 \%$ and $36 \%$ ) in indoor concrete tanks with stocking density of $1000 /$ $\mathrm{m}^{3}$, and fed on $30 \%$ crude protein $(470 \mathrm{kcal} \mathrm{ME} / 100 \mathrm{~g})$ diet for 8 weeks. The results implied that best growth for broodstocks was observed with $(36 \%)$ and no significant difference in survival. However, the least number of fry/ $\mathrm{kg}$ were produced from broodstocks reared in $36 \%$ salinity, and the highest was observed with $18 \%$. Consequently, fry delivered from broodstocks reared in high salinity level $(36 \%$ ) tolerated high salinity levels $(18 \% \circ$ and $36 \%$ ) with high survival rate $(90 \%$ and $92 \%)$ respectively, and with highest growth rate. This study highlights the importance of rearing Florida red tilapia broodstocks in saltwater in order to have offspring tolerable to marine environment.
\end{abstract}

Keywords: Florida red tilapia; Salinity levels; Tolerance; Survival; Growth performance; Production

\section{Introduction}

The shortage in freshwater in many countries, and the competition for it with agriculture and other urban activities had increased the pressure to develop aquaculture in brackish water and seawater. Though, using salt water instead of freshwater in fish farming is a worldwide priority [1]. Freshwater encompasses much lower salts and ions concentration than brackish water and seawater. Control of salt and water balance within a narrow limit is critical to life in all multicellular organisms, including teleost fishes [2]. Salt tolerance is a term describing the overall fitness, or productivity, of the fish in a saline environment [3]. It is a combination of different quantitative traits, such as metabolism, growth [4], osmoregulation [5], immunecompetence and fecundity [6]. Besides, Cnaani and Hulata [6] targeted from various culture management practices and nutrition as well as physiology and genetics to propose the best approaches for improvement of salinity tolerance in tilapias. Though tilapias normally live in freshwater, few species show high salt tolerance and could be raised in brackish water or seawater $[7,8]$.

Due to the increasing lack of freshwater in the world, it would be beneficial to culture tilapia stocks in brackish or saline rearing environments to ensure a source of cheap and high-quality animal protein into the future [9]. In general, it is well established that salinity conditions during incubation and rearing are highly relevant for embryonic development, affecting variables such as hatching rate, and even later causing a lower survival rate and deformities in larvae [10], or affecting larval size, particularly when salinity is above the species tolerance, producing smaller fish when reared at higher salt concentrations [11]. Also, there is an increasing commercial interest in tilapia species or hybrids that can tolerate salinity and still exhibit acceptable growth [12].

To date, the consumption of saltwater tilapia fish has been increased because of their tasty flesh and not too strong fishy taste rather than freshwater tilapia [13]. Tilapias are popular cultured species because of their high environmental tolerant characteristics. The rapid growth of tilapia, poor quality resistance, ability to grow under sub-optimal nutritional conditions, and high fecundity, make them well suited for aquaculture [8]. Tilapia is one of the important fish species which has several good qualities and can face wide range of salinity and other environmental conditions and can grow well in water salinities ranging from $11 \mathrm{ppm}$ to $29000 \mathrm{ppm}$, tolerate temperatures between $8^{\circ} \mathrm{C}$ to $42^{\circ} \mathrm{C}$ and can survive in low dissolved oxygen (DO) levels (0.1 ppm) [14]. Oreochromis mossambicus and its hybrids, including red tilapia are the major representatives of these euryhaline cichlids in aquaculture [15].

Based on the growth performance in saltwater, O. mossumbicus and red tilapia are competent strains for breeding tilapia in saltwater [15]. While the suitability of the Florida red tilapia strain for seawater grow-out has been demonstrated by high growth rates and feed conversion efficiencies, the hatchery phase of production remains restricted to water of lower salinities. The need for low-salinity water for maintaining broodstock and fry, thus affecting the ability of farmers to obtain fingerlings, restricts the establishment of future hatcheries in low-salinity water areas. Methods for seawater adaptation have been developed that minimize reliance on low-salinity water during the hatchery phase of production and that maximize survival and growth following transfer to seawater [16]. Other tilapias are generally less euryhaline and can tolerate water salinities ranging from about 20 to $35 \%$. Most of these tilapias grow, survive and reproduce at $0-29 \%$, depending on the species and acclimation period.

*Corresponding author: Walied A Fayed, Department of Animal and Fish Production, Faculty of Agriculture (Saba Basha), Alexandria University, Alexandria, Egypt, Tel: +20 3 5921675; E-mail: fayedwal@gmail.com

Received March 26, 2017; Accepted April 27, 2017; Published April 29, 2017

Citation: Sallam GR, Fayed WA, El-Absawy MA, Aly HA, El-Greisy ZA(2017) Red Tilapia Broodstocks and Larval Production Under Different Water Salinities Without Acclimation. J Aquac Res Development 8: 476. doi: 10.4172/2155-9546.1000476

Copyright: @ 2017 Sallam GR, et al. This is an open-access article distributed under the terms of the Creative Commons Attribution License, which permits unrestricted use, distribution, and reproduction in any medium, provided the original author and source are credited. 
Salinity tolerance of tilapia is also affected by fish sex and size. Perschbacher and McGeachin [17] evaluated the salinity tolerance of red tilapia (O. mossambicus $\times$ O. urolepis hornorum) fry, juveniles and adults. Adult fish were more salt-tolerant than fry and juveniles. Fry and juveniles tolerated direct transfer to $19 \%$, without apparent stress and mortality, but $100 \%$ mortality occurred at $27 \%$. On the other hand, adult fish tolerated a direct transfer to $27 \%$, with $100 \%$ mortality at $37 \%$. Similarly, Watanabe et al. [18] studied the ontogeny of salinity tolerance in Nile tilapia, blue tilapia and hybrids tilapia $(O$. mossambicus female $\times$ O. niloticus) was referred to body size than to chronological age. The median lethal salinity-96 h (MLS-96) for Nile tilapia and blue tilapia over an age of 7-120 days post-hatching (dph) was 18.9 and $19.2 \%$. In contrast, MLS-96 of tilapia hybrids changed with age and increased from $17.2 \%$ at $30 \mathrm{dph}$ to $26.7 \%$ at $60 \mathrm{dph}$ [18]. Also, Watanabe et al. [18] reported also that male tilapia tend to be more salt tolerant than females. It has also been reported that tilapia hybrids descended from salt-tolerant parents (such as O. mossambicus and $O$. aureus) are highly salt-tolerant [19]. This may explain why Taiwanese red tilapia [20] and Florida red tilapia [21] grow faster in seawater and brackish water than in freshwater.

The sudden salinity changes may impact the physiological condition of the fish and the tolerance limits of the fish will cause stress and lead to decrease the immune system level. Rearing Tilapia in saltwater could have no different between freshwater. The Tilapia appeared normal and healthy through the external observation in saltwater but the level of stress with the sudden introduced to different salinity level unknown [13]. However, previous research by Sharif et al. [22] demonstrated that survival of red tilapia fry decreased with increasing salinity from $16 \%$ to $40 \%$ with acclimation after 12 days. Moreover, final body weight of Florida red tilapia fry was found to decrease significantly with increasing salinity from $16 \%$ to $32 \%$ after gradual acclimation period [23], and increases non-significantly with increased salinity from $0 \%$ to 25\% [24]. Also, feed conversion rate of Florida red tilapia fry elevated significantly with increasing salinity from $16 \%$ to $32 \%$ [ [23]

Therefore, the objectives of the present study have two main approaches: first, determine the growth performance of Florida red tilapia broodstocks in different salinity levels; and second, is to produce Florida red tilapia fry that could tolerate and survive the direct transfer to marine water without being acclimated.

\section{Materials and methods}

\section{Experimental location and fish species}

This study was conducted on Florida red tilapia, Oreochromis sp., fingerlings for 32 weeks in El-Max Research Station, National Institute of Oceanography and Fisheries (NIOF), Alexandria, Egypt.

Experimental fish and acclimatization condition: Four hundred fingerlings with initial body weight (IBW) of $29.4 \pm 0.12 \mathrm{~g}$ were acclimated in fiberglass tanks for 6 weeks with a density of $10 / \mathrm{m}^{3}$ on four salinity (part per thousand, ppt) levels ( $9 \%, 18 \%, 24 \%$, and $36 \%$ ) and a freshwater as a control treatment. Females and males were placed separately and fed to satiation on $30 \%$ CP $470 \mathrm{Kcal} \mathrm{ME} / 100 \mathrm{~g}$ diet during the acclimation period. Florida red tilapia, Oreochromis sp. were gradually acclimated to the respective treatment of salinities by raising the salinity at the rate of $4 \%$ daily [18].

Experimental design: This study was designed to embrace two phases in which the first reveal the effect of different salinity levels $(9 \%, 18 \%, 24 \%$, and $36 \%$ ) on broodstocks growth performance and fry production. Whereas the second phase involve the effect of broodstocks acclimation salinity levels on the tolerance of produced fry to survive and grow in different salinity levels (9\%, $18 \%$, and $36 \%$ ) without acclimation.

Following the acclimatization period, the fish were transferred to ten concrete tanks with dimensions of $4 \mathrm{~m} \times 2 \mathrm{~m} \times 1 \mathrm{~m}$ (length $\times$ width $\times$ depth) representing 5 treatments each with two replicates. The tanks were continuously aerated to maintain dissolved oxygen level to 6.5 $\mathrm{mg} / \mathrm{l}$, and $\mathrm{pH}$ level of 7.5-9, and temperature $28 \pm 2{ }^{\circ} \mathrm{C}$. Each replicate was stocked with $5 \mathrm{fish} / \mathrm{m}^{3}$ (total of $40 \mathrm{fish}$ ) both females and males with ratio of $(3: 1)$ allocated for spawning. Fish were fed $1 \%$ of their body weight on commercial diet encompassing $25 \%$ crude protein (CP) twice daily 7 days a week for 16 weeks. Every 10 days' fish were weighed and female brooders were checked for fry.

Twelve weeks after the onset of spawning, fry was collected from broodstocks subjected to the five salinity levels for the onset of the second phase of the experiment. Each batch of fry from a broodstock of different level of salinity was exposed to three different salinity levels, low, medium and high (9\%, 18\%o, and 36\%, respectively) for 8 weeks without initial acclimatization period. The offspring were stocked with rate of $1000 \mathrm{fry} / \mathrm{m}^{3}$ in 30 (15 treatments $\times 2$ replicates) concrete tanks ( $1 \mathrm{~m}^{3}$ each tank). Feed offered to fry to satiation on an isocaloric diet ( $30 \% \mathrm{CP}$ and $470 \mathrm{Kcal} \mathrm{ME} / 100 \mathrm{~g}$ diet). Fry were observed for survival and mortality rates were recorded.

\section{Fish growth and feed utilization parameters}

Growth performance and feed utilization of Florida red tilapia was determined, and was calculated as follows:

$$
\text { Specific Growth Rate }(S G R) \text { (in percent per day) }=\frac{100\left[\operatorname{Ln} W_{2}-\operatorname{Ln} W_{1}\right]}{T}
$$

Where $\mathrm{W} 1$ and $\mathrm{W} 2$ are the initial and the final weights, respectively, and $\mathrm{T}$ is the number of days of the experiment;

$$
\begin{aligned}
& \text { Feed Conversion Ratio }(\mathrm{FCR})=\frac{\text { feed intake }[\text { in grams }]}{\text { weight gain }[\text { in grams }]} \\
& \text { Protien Efficiency Ratio }(\text { PER })=\frac{\text { weight gain }[\text { in grams }]}{\text { protien intake }[\text { in grams }]}
\end{aligned}
$$

\section{Statistical analysis}

Results of growth parameters, feed utilization parameters, and survival rate (\%) of broodstocks and fry of the experimental treatments were treated using the ANOVA test (analysis of variance) and Tuckey test to a minimum significance $(\mathrm{P}<0.05)$. The results are expressed as means \pm SEM. Statistical analysis was performed using one-way ANOVA according to Assaad et al. [25] and EXCEL (windows 10, 2015).

\section{Results}

\section{Broodstocks growth performance and feed utilization}

Acclimatization period of 6 weeks, fingerlings with initial body weight of $29.4 \mathrm{~g}$ reached maturation and started to spawn after 7 weeks of acclimation. Fish were subjected to four salinity levels (9\%, $18 \%$, $24 \%$, and $36 \%$ ) and a freshwater as control treatment. The final body weight (FBW) and weight gain (WG) of fish after 24 weeks was significantly different $(\mathrm{P}<0.05)$ between treatments, showing increase with increasing salinity level (Table 1). Consequently, average daily gain (ADG), and specific growth rate (SGR\%) revealed similar patterns as FBW and WG. The highest ADG, and SGR\% was observed 


\begin{tabular}{|c|c|c|c|c|c|}
\hline Variables & C & $9 \%$ & $18 \%$ & $24 \%$ & $36 \%$ \\
\hline FBW & $163 \pm 1.75^{d}$ & $187 \pm 9.13^{\text {cd }}$ & $232 \pm 0.83^{\mathrm{bc}}$ & $257 \pm 16.6^{b}$ & $364 \pm 16.6^{a}$ \\
\hline WG & $94.8 \pm 0^{d}$ & $119 \pm 8.58^{\mathrm{cd}}$ & $161 \pm 0.78^{b c}$ & $185 \pm 15.6^{b}$ & $285 \pm 15.6^{a}$ \\
\hline ADG & $0.53 \pm 0^{d}$ & $0.66 \pm 0.05^{\mathrm{cd}}$ & $0.9 \pm 0.004^{b c}$ & $1.03 \pm 0.09^{b}$ & $1.58 \pm 0.09^{a}$ \\
\hline SGR $\%$ & $0.49 \pm 0^{d}$ & $0.56 \pm 0.023^{c d}$ & $0.66 \pm 0.002^{b c}$ & $0.71 \pm 0.03^{b}$ & $0.85 \pm 0.02^{\mathrm{a}}$ \\
\hline SVR\% & $92.5 \pm 0.5$ & $96 \pm 1$ & $81 \pm 12$ & $100 \pm 0$ & $100 \pm 0$ \\
\hline FCR & $1.35 \pm 0.02^{b}$ & $1.4 \pm 0.01^{b}$ & $1.6 \pm 0.015^{\mathrm{a}}$ & $1.64 \pm 0.025^{a}$ & $1.7 \pm 0.015^{a}$ \\
\hline PER & $2.96 \pm 0.044^{a}$ & $2.86 \pm 0.02^{a}$ & $2.49 \pm 0.02^{b}$ & $2.45 \pm 0.04^{b}$ & $2.35 \pm 0.021^{b}$ \\
\hline Total no. Fry & $896 \pm 0^{c}$ & $1140 \pm 58.9^{b c}$ & $1680 \pm 6.29^{a}$ & $1270 \pm 85.3^{b}$ & $1300 \pm 61.2^{b}$ \\
\hline Fry/kg & $6.88 \pm 0^{c}$ & $7.68 \pm 0.07^{b}$ & $9.37 \pm 0^{\mathrm{a}}$ & $6.53 \pm 0^{d}$ & $4.88 \pm 0.03^{\mathrm{e}}$ \\
\hline
\end{tabular}

Values are means $\pm \mathrm{SEM}, \mathrm{n}=2$ per treatment group.

Means in a row without a common superscript letter differ $(P<0.05)$ as analyzed by one-way ANOVA and the TUKEY test.

Table 1: Mean values of final body weight (FBW, $g$ fish $\left.{ }^{-1}\right)$, weight gain (WG, $g$ fish ${ }^{-1}$ ), average daily gain $\left(A D G, g\right.$ fish ${ }^{-1}$ day $\left.^{-1}\right)$, specific growth rate $(S G R, \%)$, survival rate (SUR, \%), protein efficiency ratio (PER), feed conversion rate (FCR), total number of fry (TF, fry female ${ }^{-1}$ ), and number of fry $\mathrm{kg}^{-1}$ of Florida red tilapia Oreochromis sp. broodstocks reared in different salinity levels and control $(\mathrm{C})$ freshwater treatment.

\begin{tabular}{|c|c|c|c|c|c|}
\hline Variables & C & $9 \%$ & $18 \%$ & $24 \%$ & $36 \%$ \\
\hline Low & $97.5 \pm 0.5^{a}$ & $87.9 \pm 0.48^{b}$ & $90.7 \pm 1.44^{b}$ & $87.2 \pm 1.96^{b}$ & $70.8 \pm 0.25^{c}$ \\
\hline Medium & $79.5 \pm 0.5^{b}$ & $86 \pm 5.23^{\mathrm{ab}}$ & $91.2 \pm 0.96^{\mathrm{ab}}$ & $94.4 \pm 2.19^{a}$ & $96.9 \pm 0.45^{a}$ \\
\hline High & -- & $18.8 \pm 4.19^{c}$ & $73 \pm 3.84^{b}$ & $95.7 \pm 0.67^{\mathrm{a}}$ & $96.8 \pm 0.23^{a}$ \\
\hline
\end{tabular}

Values are means \pm SEM, $\mathrm{n}=2$ per treatment group.

Means in a row without a common superscript letter differ $(P<0.05)$ as analyzed by one-way ANOVA and the TUKEY test.

Table 2: Mean values ( \pm SER) of survival percentage $(\%)$ of Florida red tilapia fry reared in three salinity levels (low, medium, and high) delivered from broodstocks subjected to the 4 salinity levels and control (C) freshwater treatment.

with $(36 \%$ ) level with values of $1.58 \pm 0.09 \mathrm{~g} / \mathrm{fish} /$ day, and $0.85 \pm$ 0.02 , respectively. Whereas for broodstock survival rate, revealed no significant difference between treatments, however, the $(24 \%$, and $36 \%$ ) treatments demonstrated high survival rate followed by $(9 \%$ ) then the control treatment (freshwater), and the lowest was found to be for the broodstocks subjected to (18\%) salinity level (Table 1).

In spite of that the growth performance of Florida red tilapia showed a linear relationship with the salinity levels, but the FCR of broodstocks demonstrated a significant $(\mathrm{P}<0.05)$ inverse correlation with salinity levels. The broodstocks in freshwater treatment showed an improved significant FCR than with broodstocks in $(9 \%, 18 \%, 24 \%$, and $36 \%$ ) respectively (Table 1). On the same manner, the PER showed similar trend as the FCR and implying that feed utilization parameters was significant lower with $(18 \%, 24 \%$, and $36 \%$ ) than the control and (9\%) salinity level (Table 1 ).

\section{Fry production}

However, broodstocks showed different trend than FBW and WG in significance between treatments for average total number of fry produced and mean fry produced per kilogram fish (Table 1). The results displayed that $(18 \%)$ salinity level had the significant highest total number of fry and fry/kg with values of $1680 \pm 6.29$ fry/fish and $9.37 \pm 0$ fry $/ \mathrm{kg}$ (Table 1). Although, the lowest significant $(\mathrm{P}<0.05)$ number of fry produced ( $896 \pm 0$ fry/fish) was observed for the control treatment (freshwater), but the lowest significant $(\mathrm{P}<0.05) 4.88 \pm 0.03$ fry $/ \mathrm{kg}$ was obtained from $36 \%$ salinity level treatment (Table 1 ).

\section{Fry survival rate}

The fry survival is one of the main objectives for the present study, where the results obtained revealed that fry delivered from freshwater broodstock when exposed to high (36\%) salinity level had mortality of $100 \%$ after the first week of exposure (Table 2). However, same treatment fry (control) had survival rate of $97.5 \%$ and $79.5 \%$ by the end of the experimental study, when subjected to $9 \%$ and $18 \%$ salinity levels, respectively (Table 2). However, when comparing survival rate of fry delivered from broodstock of different salinity levels ( $9 \%$,
$18 \%$, $24 \%$, and $36 \%$ ) with fry from control treatment broodstock (freshwater) at low (9\%) salinity level, the results demonstrates that fry from freshwater had the highest significant $(\mathrm{P}<0.05)$ survival rate than all others.

Moreover, when increasing salinity level that fry are subjected to medium, the survival rate is enhanced for fry from broodstock exposed to $(9 \%, 18 \%, 24 \%$, and $36 \%$ ), showing that the highest significant $(\mathrm{P}<0.05)$ survival rate $(96.9 \pm 0.45 \%)$ was for fry delivered from broodstocks $(36 \%)$ and the lowest $(79.5 \pm 0.5)$ for fry from control treatment broodstock. Similarly, the survival rate of fry delivered from broodstock $(36 \%$ ) showed the same trend when subjected to high salinity level compared to all other treatments (Table 2). This could be explained that when fry of Florida red tilapia broodstocks are reared in marine water their offspring could possibly tolerate high salinity (marine environment) levels without being acclimatized. And when those fry are exposed to lower salinity than that of their broodstocks their survival might be affected and could alleviate their mortality rate. Therefore, fry of Florida red tilapia should be acclimatized if reared in salinity levels different than that of their broodstocks, thus, tolerating salinity for offspring may be considered a maternal effect.

\section{Fry growth performance and feed utilization}

Correspondingly, the FBW and ADG of fry showed a parallel significant results as survival rate trend, which at low salinity level fry delivered from broodstocks exposed to freshwater and (9\%) salinity had significant $(\mathrm{P}<0.05)$ higher FBW and ADG than those delivered from $(18 \%, 24 \%$, and $36 \%$ ) respectively (Tables 3 and 4$)$. However, the FBW and ADG trends are inversed when medium and high salinity levels are imposed.

Meanwhile, the FCR and PER of the broodstock showed an inverse significant relation with the salinity level (Tables 5 and 6), but the offspring delivered from broodstock subjected to elevated salinity levels had a better significant $(\mathrm{P}<0.05)$ FCR and PER when exposed to medium and high salinity levels than those from control and $(9 \%)$ broodstocks. Therefore, the present study determines the importance of culturing Florida red tilapia broodstocks in marine water that induces 


\begin{tabular}{|c|c|c|c|c|c|}
\hline Variables & $\mathbf{C}$ & $\mathbf{9 \%}$ & $\mathbf{1 8} \% \circ$ & $\mathbf{2 4} \% 0$ & $\mathbf{3 6} \% 0$ \\
\hline Low & $11.3 \pm 0^{\mathrm{a}}$ & $9.77 \pm 0.22^{\mathrm{bc}}$ & $10 \pm 0.18^{\mathrm{b}}$ & $9.11 \pm 0.005^{\mathrm{c}}$ & $9.88 \pm 0.11^{\mathrm{b}}$ \\
\hline Medium & $7.38 \pm 0.39^{\mathrm{d}}$ & $9 \pm 0.12^{\mathrm{c}}$ & $12.3 \pm 0.28^{\mathrm{b}}$ & $13.5 \pm 0.05^{\mathrm{ab}}$ & $14.7 \pm 0.33^{\mathrm{a}}$ \\
\hline High & -- & $7.5 \pm 0.38^{\mathrm{c}}$ & $12.5 \pm 0.105^{\mathrm{b}}$ & $14.1 \pm 0.12^{\mathrm{a}}$ & $14.9 \pm 0.39^{\mathrm{a}}$ \\
\hline
\end{tabular}

Values are means \pm SEM, $n=2$ per treatment group.

Means in a row without a common superscript letter differ $(P<0.05)$ as analyzed by one-way ANOVA and the TUKEY test.

Table 3: Mean values $\left( \pm\right.$ SER) of final body weight $\left(\mathrm{g} \mathrm{fish}^{-1}\right)$ of Florida red tilapia fry reared in three salinity levels (low, medium and high) delivered from broodstocks subjected to the 4 salinity levels and control $(C)$ freshwater treatment.

\begin{tabular}{|c|c|c|c|c|c|}
\hline Variables & $\mathbf{C}$ & $\mathbf{9 \%}$ & $\mathbf{1 8} \% \mathrm{o}$ & $\mathbf{2 4 \%}$ & $\mathbf{3 6} \%$ \\
\hline Low & $0.2 \pm 0^{\mathrm{a}}$ & $0.17 \pm 0.004^{\mathrm{bc}}$ & $0.18 \pm 0.003^{\mathrm{b}}$ & $0.16 \pm 0.00001^{\mathrm{c}}$ & $0.18 \pm 0.002^{\mathrm{b}}$ \\
\hline Medium & $0.13 \pm 0.01^{\mathrm{d}}$ & $0.16 \pm 0.002^{\mathrm{c}}$ & $0.22 \pm 0.01^{\mathrm{b}}$ & $0.24 \pm 0.001^{\mathrm{ab}}$ & $0.26 \pm 0.01^{\mathrm{a}}$ \\
\hline High & -- & $0.13 \pm 0.01^{\mathrm{c}}$ & $0.22 \pm 0.002^{\mathrm{b}}$ & $0.25 \pm 0.002^{\mathrm{a}}$ & $0.27 \pm 0.01^{\mathrm{a}}$ \\
\hline
\end{tabular}

Values are means \pm SEM, $n=2$ per treatment group.

Means in a row without a common superscript letter differ $(P<0.05)$ as analyzed by one-way ANOVA and the TUKEY test.

Table 4: Mean values $\left( \pm\right.$ SER) of average daily gain $\left(\mathrm{g} \mathrm{fish}^{-1}\right.$ day $\left.^{-1}\right)$ of Florida red tilapia fry reared in three salinity levels (low, medium and high) delivered from broodstocks subjected to the 4 salinity levels and control $(C)$ freshwater treatment.

\begin{tabular}{|c|c|c|c|c|c|}
\hline Variables & $\mathbf{C}$ & $\mathbf{9 \%}$ & $\mathbf{1 8 \%}$ & $\mathbf{2 4 \%}$ & $\mathbf{3 6 \%}$ \\
\hline Low & $1.61 \pm 0.05$ & $1.6 \pm 0.05$ & $1.59 \pm 0.01$ & $1.52 \pm 0.04$ & $1.56 \pm 0.04$ \\
\hline Medium & $1.6 \pm 0.03^{\mathrm{a}}$ & $1.58 \pm 0.03^{\mathrm{ab}}$ & $1.53 \pm 0^{\mathrm{ab}}$ & $1.42 \pm 0.03^{\mathrm{bc}}$ & $1.28 \pm 0.05^{\mathrm{c}}$ \\
\hline High & -- & $1.49 \pm 0.05^{\mathrm{a}}$ & $1.39 \pm 0.05^{\mathrm{a}}$ & $1.38 \pm 0.03^{\mathrm{a}}$ & $1.12 \pm 0.01^{\mathrm{b}}$ \\
\hline
\end{tabular}

Values are means \pm SEM, $n=2$ per treatment group.

Means in a row without a common superscript letter differ $(P<0.05)$ as analyzed by one-way ANOVA and the TUKEY test.

Table 5: Mean values ( \pm SER) of feed conversion rate (FCR) of Florida red tilapia fry reared in three salinity levels (low, medium and high) delivered from broodstocks subjected to the 4 salinity levels and control (C) freshwater treatment.

\begin{tabular}{|c|c|c|c|c|c|}
\hline Variables & $\mathbf{C}$ & $\mathbf{9 \%}$ & $\mathbf{1 8 \%}$ & $\mathbf{2 4 \%} \%$ & $\mathbf{3 6 \%}$ \\
\hline Low & $2.49 \pm 0.08$ & $2.5 \pm 0.08$ & $2.52 \pm 0.02$ & $2.62 \pm 0.06$ & $2.57 \pm 0.07$ \\
\hline Medium & $2.5 \pm 0.05^{\mathrm{b}}$ & $2.54 \pm 0.04^{\mathrm{b}}$ & $2.61 \pm 0.00^{\mathrm{b}}$ & $2.83 \pm 0.05^{\mathrm{ab}}$ & $3.13 \pm 0.12^{\mathrm{a}}$ \\
\hline High & -- & $2.69 \pm 0.09^{\mathrm{b}}$ & $2.88 \pm 0.104^{\mathrm{b}}$ & $2.91 \pm 0.053^{\mathrm{b}}$ & $3.57 \pm 0.032^{\mathrm{a}}$ \\
\hline
\end{tabular}
Values are means \pm SEM, $n=2$ per treatment group.

Means in a row without a common superscript letter differ $(P<0.05)$ as analyzed by one-way ANOVA and the TUKEY test.

Table 6: Mean values ( \pm SER) of protein efficiency ratio (PER) of Florida red tilapia fry reared in three salinity levels (low, medium, and high) delivered from broodstocks subjected to the 4 salinity levels and control $(C)$ freshwater treatment.

and enhances the offspring growth performance and feed utilization in marine environment without being acclimatized.

\section{Discussion}

Pre-acclimation to salt water and gradual transfer to high salinity have a significant effect on tilapia growth and survival, as has been reported by Al-Amoudi [26]. Acclimation period varies between tilapia species where $O$. aureus, O. mossambicus and $O$. spilurus required shorter acclimation time (4 days) for a transfer to full-strength seawater than $O$. niloticus and $O$. aureus $\times O$. niloticus hybrids ( 8 days) [26]. The author suggested that the physiological changes associated with seawater acclimation in tilapia are short-term, energy demanding and may account for as much as $20 \%$ of total body metabolism after 4 days in seawater. However, Florida red tilapia has been acclimated for 6 weeks in the present study on gradual salinity increase to reach full-strength seawater salinity in order not to pause any stress on fish.

Many researchers handled different aspects of acclimation of tilapia to elevated salinity levels through water salinity or diets containing various salt levels. Turingan and Kubaryk [27] supplemented Taiwanese red tilapia $(O$. mossambicus $\times$ O. niloticus) broodstock with diets containing higher salt levels may produce seeds with better adaptability to water salinity. They found that egg hatchability was higher in seawater than in freshwater. The hatchability and larval growth were highest in seawater than in freshwater when fish received $12 \%$ salt in their diets.

Rengmark and Lingaas [28] investigated the role of transferrin, an iron-binding glycoprotein known to have an important role in the immune system, on salinity tolerance. They cloned and sequenced entire transferrin gene of tilapia and compared the expression levels in saltwater and freshwater reared tilapia using real-time PCR. Rengmark and Lingaas [28] observed that transferrin showed an $85 \%$ upregulation in tilapia kept in saltwater compared to freshwater, suggesting that transferrin or closely-linked genes may be involved in saltwater tolerance. In the present study, the survival rate of Florida red tilapia broodstocks was high and did not differ significantly for all treatments which implied that acclimation process was successfully applied with no stress or osmoregulatory failure in fish. Moreover, growth performance of Florida red tilapia herein increased significantly with the increase of water salinity that might be due to minimal metabolic energy diversion into osmoregulation. In support, Watanabe et al. [29] found that the daily feed consumption of Florida red tilapia fed a $32 \%$ $\mathrm{CP}$ diet increased with increasing salinity from 0 to $32 \%$.

The increase in the metabolic energy diverted into osmoregulation, with increasing water salinity has also been reported in O. mossambicus and O. spilurus [30], O. niloticus $\times$ O. aureus and common carp [31] Previous studies indicated that growth rates of Florida red tilapia reared at different salinities increased with increasing temperature within the range $22^{\circ} \mathrm{C}$ to $32^{\circ} \mathrm{C}$ [32]. In accordance to the present study, experimental period was conducted in similar range of temperatures which favored the growth performance of Florida red tilapia.

Moreover, the better growth performance in saline water might be attributed to higher osmoregulation energy costs in freshwater than in brackish water or seawater for O. mossambicus $\times$ O. hornorum hybrid [33], suppressed territorial aggression by salinity [21], and inhibitory effects of aggressive behavior which varied among different salinities [20]. These results support the common assumption that growth of euryhaline teleosts is increased at salinities near iso-osmotic, since osmoregulation costs are minimal under these conditions [33]. On the contrary, Watanabe et al. [29] denoted that the growth of Florida red tilapia at salinities near iso-osmotic was found to be lower than that at higher salinities which was attributed to increased food consumption and lowered food conversion ratio in high salinity. Although, the results of the broodstocks FCR obtained in the present study were found to match that of Watanabe et al. [29] in which broodstocks from lower salinity treatments showed an improved significant FCR than that of higher salinities. But the broodstocks growth performance in the present study contradicts with the findings of Watanabe et al. [29] and corresponds with Febry and Lutz [33].

In addition, many researchers demonstrated that at equivalent salinity early exposure of tilapia broodstock to high salinity produced progeny with high salinity tolerance than those spawned in freshwater and hatched at high salinity. Respectively, produced fry in the present study delivered from freshwater broodstock when exposed to high salinity level had mortality of $100 \%$ after the first week of exposure. However, when comparing survival rate of fry delivered from broodstock of different salinity levels ( $9 \%, 18 \%$, $24 \%$, and $36 \%$ ) with fry from control treatment broodstock (freshwater) at low (9\%o) salinity level, the results demonstrates that fry from freshwater had the highest significant $(\mathrm{P}<0.05)$ survival rate than all others. Moreover, when 
increasing salinity level for fry the survival rate is enhanced showing that the highest significant $(\mathrm{P}<0.05)$ survival rate was for fry delivered from broodstock $(36 \%)$ and the lowest for fry from control treatment broodstock. Therefore, early exposure of broodstocks to high salinity benefits produced fry to tolerate direct exposure to marine water without acclimation. Thus, the Florida red tilapia might be cultured successfully in marine water with demanding freshwater.

On the other hand, Hassan et al. [13] observed that the mortality rate of red tilapia fingerlings increased with increasing salinity level from $0 \%$ to $35 \%$, and reached $100 \%$ mortality after 4 days of exposure. In 1989, Reference [16] assessed the influence of spawning salinity on survival and growth in brackish or seawater, growth of juveniles, suggesting that progeny spawned under elevated salinities are better adapted for growth in brackish and seawater. In the same manner, Sharif et al. [22] revealed that, survival of red tilapia decrease from $98 \%$ to $79.2 \%$ with increasing salinity from $16 \%$ to $40 \%$ after 12 days. Moreover, Hassan et al. [13] indicated that the direct transfer of freshwater adapted red tilapia to marine water causes $100 \%$ mortality due to respiratory distress and osmoregulatory exhaustion, which leads to increase osmotic concentration of blood serum and change in ionic contents. And since the chloride cells are the ionic regulator and extrusion in gill epithelia of sea adapted fish [34,35], Sharif et al. [22] noticed the formation of the chloride cells in gills of marine water adapted red tilapia and its absence in freshwater red tilapia. Moreover, Sharif et al. [22] stated that the chloride cells were observed in fish after 2 weeks in marine water. The author indicates that the acclimation of freshwater red tilapia needed about 2 weeks to be able to live in marine water. Correspondingly, this could explain the increased mortality of red tilapia fry from broodstock reared in freshwater when exposed to high salinity levels without acclimation in the present study, and the ability of fry descended from broodstocks reared in high levels of salinity to tolerate and survive without acclimatization.

Concurrently, Hibiya [36] disclosed that activation of chloride cells when fresh eel adapted to sea water is noted within 2 to 4 days and gills take one month to be completed of the sea water type. Lowsalinity water requirements during the hatchery phase of production may be reduced by acclimating stocks to seawater at early stages of development [18]. Despite of survival rate, broodstock from brackish water $(18 \%)$ displayed the highest total number of fry and fry $/ \mathrm{kg}$, but the lowest number of fry produced was observed for the control treatment, and the lowest fry $/ \mathrm{kg}$ was from seawater treatment.

In support to obtained results in the present study, Watanabe et al. [16] observed that fry production per unit female weight declined at salinities above $18 \%$ suggesting that Florida red tilapia broodstock may be maintained under salinities as high as $18 \%$ without impairing fry production. Although, FBW and FCR of fry showed a linear trend as survival rate, which at low salinity level fry delivered from broodstocks exposed to freshwater and low salinity had higher FBW and enhanced FCR than those from brackish and seawater. However, the FBW and FCR trends are inversed when medium and high salinity levels are imposed. However, Vũ [24] implied that final body weight of Florida red tilapia fry increased non-significantly with increased salinity from freshwater to $25 \%$.

On the contrary, El-Zaeem et al. [23] stated that final body weight of Florida red tilapia fry decreased significantly from $33.38 \mathrm{~g}$ to 18.68 g with increasing salinity from $16 \%$ to $32 \%$, respectively, after gradual acclimation period. Moreover, El-Zaeem et al. [23] found that FCR was elevated significantly Florida red tilapia fry with increasing salinity from $16 \%$ to $32 \%$.

\section{Conclusion}

It could be concluded from the present study that growth performance and survival rate of Florida red tilapia, Oreochromis sp., broodstocks increases with increasing salinity after gradual acclimation. Also, when fry of Florida red tilapia from acclimated broodstocks are reared in marine water they could possibly tolerate high salinity (marine environment) levels without acclimation. Therefore, the study highlights the possibility of acclimation of Florida red tilapia broodstocks on high salinity levels produces seeds that could tolerate the direct transfer to marine water without requiring acclimation.

\section{Ethical Issues}

We certify that all data collected during this study is presented in this manuscript and no data from the present study has been or will be published separately or elsewhere.

\section{References}

1. El-Sayed MA (2006) Tilapia culture in salt water: environmental requirements, nutritional implication and economic potentials. Avances en Nutrició Acuícola VIII. VIII Simposium internacional de Nutrición. Acuícola. Universidad Autónoma de Nuevo León, Monterrey, Nuevo León, Mexico.

2. Jeanette CF, Amy K, Liza M, Larry GR, Paul HY, et al. (2007) Effects of environmental salinity and temperature on osmoregulatory ability, organic osmolytes, and plasma hormone profiles in the Mozambique tilapia (Oreochromis mossambicus). Comp Biochem Physiol A Mol Integr Physiol 146 252-264.

3. Stickney RR (1986) Tilapia resistance of saline waters: A review. Pro FishCult 48: 161-167.

4. Sakamoto T, McCormick SD (2006) Prolactin and growth hormone in fish osmoregulation. Gen and Comp Endocri 147: 24-30.

5. Mancera JM, McCormick SD (2007) Role of prolactin, growth hormone, insulinlike growth factor I and cortisol in teleost osmoregulation. Fish Osmoregulation, Science Publishers, Enfield, NH.

6. Cnaani A, Hulata G (2011) Improving salinity tolerance in tilapias: Past experience and future prospects. The Isra J Aquac-Bamidg 63: 533-554

7. Kamal AM, Mair GC (2005) Salinity tolerance in superior genotypes of tilapia, Oreochromis niloticus, Oreochromis mossambicus and their hybrids. Aquaculture 247: 189-201.

8. Lawson EO, Anetekhai MA (2011) Salinity tolerance and preference of hatchery reared Nile Tilapia, Oreochromis niloticus (Linnaeus 1758). Asian J Agri Sci 3 : 104-110.

9. Mateen A (2007) Effect of androgen on the sex reversal, growth and meat quality of tilapia, Oreochromis niloticus. Department of Zoology and Fisheries, University of Agriculture, Faisalabad, Pakistan.

10. Takuma O, Tadahide K, Koichiro G, Koji M, Kazuharu N (2009) Influence of salinity on morphological deformities in cultured larvae of Japanese eel, Anguilla japonica, at completion of yolk resorption. Aquaculture 293: 113-118.

11. Fielder DS, Bardsley WJ, Allan DL, Pankhurst PM (2005) The effects of salinity and temperature on growth and survival of Australian snapper, Pagrus auratus larvae. Aquaculture 250: 201-214.

12. Armas-Rosales, MA (2006) Genetic effects influencing salinity and cold tolerance in tilapia. Louisiana State University, Agricultural and Mechanical College, USA.

13. Hassan M, Zakariah MI, Wahab W, Muhammad SD, Idris N (2013) Histopathological and behavioral changes in Oreochromis sp. after exposure to different salinities. J Fish Livest Prod 1: 103

14. Pullin, RSV, Lowe-McComell RH (1982) The biology and culture of tilapias. International Center for Living Aquatic Resources Management, Manila Philippines.

15. Tayamen MM, Reyes RA, Danting MJ, Mendoza AM, Marquez EB, et al, (2002) Tilapia broodstock development for saline waters in the Philippines. NAGA ICLARM Quarterly 25: 32-36. 
Citation: Sallam GR, Fayed WA, El-Absawy MA, Aly HA, El-Greisy ZA(2017) Red Tilapia Broodstocks and Larval Production Under Different Water Salinities Without Acclimation. J Aquac Res Development 8: 476. doi: 10.4172/2155-9546.1000476

16. Watanabe WO, Ernst DH, Olla BL, Wicklund RI (1989) Aquaculture of red Tilapia (Oreochromis sp.) in marine environments state of the art. Adv in Trop Aquac 487-498.

17. Perschbacher PW, McGeachin RB (1988) Salinity tolerance of red hybrid tilapia fry, juvenile and adults. Proceedings of the Second International Symposium on Tilapia in Aquaculture ICLARM Conference Philippines.

18. Watanabe WO, Kuo CM, Huang MC (1985) The ontogeny of salinity tolerance in the tilapias Oreochromis aureus, O. niloticus, and an O. mossambicus $\times 0$. niloticus hybrid, spawned and reared in freshwater. Aquaculture 47: 353-367.

19. Romana-Eguia MR, Eguia RV (1999) Growth of five Asian red tilapia strains in saline environments. Aquaculture 173: 161-170.

20. Liao IC, Chang SL (1983) Studies on the feasibility of red tilapia culture in saline water. Proceeding of the International Symposium on Tilapia in Aquaculture. Tel Aviv University, Tel Aviv, Israel.

21. Watanabe WO, French KE, Ellingson LJ, Wicklund RI, Olla BL (1988b) Further investigations on the effects of salinity on growth of Florida red tilapia: evidence for the influence of behavior. The second International Symposium on Tilapia in Aquaculture, Philippines.

22. Sharaf MM, Sharaf SM, El-Marakby HI (2004) The effect of acclimatization of freshwater red hybrid tilapia in marine water. Pak J Biol Sci 7: 628-632.

23. El-Zaeem SY, Ahmed MM, Salama ME, Darwesh DMF (2012) Production of salinity tolerant tilapia through interspecific hybridization between Nile tilapia (Oreochromis niloticus) and red tilapia (Oreochromis sp.). Afr J Agri Res 7: 2955-2961.

24. Vũ AP (2013) Effect of salinity on growth and feed utilization of Nile tilapia (Oreochromis niloticus) and red tilapia (Oreochromis sp.). Vietnam National University, Vietnam.

25. Assaad H, Zhou L, Carroll RJ, Wu G (2014) Rapid publication-ready MS-Word tables for one-way ANOVA. Springer Plus 3: 474.

26. Al-Amoudi MM (1987) Acclimation of commercially cultured Oreochromis species to sea water-an experimental study. Aquaculture 65: 333-342.
27. Turingan JE, Kubaryk JM (1992) The effect of high salt diet on survival and hatchability of Taiwanese red tilapia (O. mossambicus $\times$ O. niloticus) eggs upon direct transfer to seawater. Aquac 92- Book of Abstract. W Aquac Soc Baton Rouge, Louisiana, USA.

28. Rengmark AH, Lingaas $F$ (2007) Genomic structure of the Nile tilapia (Oreochromis niloticus) transferrin gene and a haplotype associated with saltwater tolerance. Aquaculture 272: 146-155.

29. Watanabe WO, Ellingson LJ, Wicklund RI, Olla BL (1988a) The effects of salinity on growth, food consumption and conversion in juvenile monosex male Florida red tilapia. The Second International Symposium on Tilapia in Aquaculture, Philippines.

30. Payne AL, Ridgway J, Hamer JL (1988) The influence of salt $(\mathrm{NaCl})$ concentration and temperature on the growth of Oreochromis spilurus, $\mathrm{O}$. mossambicus and a red tilapia hybrid". The Second International Symposium on Tilapia in Aquaculture. Philippines.

31. Payne AL (1983) Estuarine and salt tolerant tilapia. In: Proceedings, International Symposium on Tilapia in Aquaculture. Tel Aviv University, Israel.

32. Watanabe WO, Ernst DH, Chasar MP, Wicklund RI, Olla BL (1993) The effects of temperature and salinity on growth and feed utilization of juvenile, sex reversed male Florida red tilapia cultured in a recirculating system. Aquaculture 112: 309-320.

33. Febry R, Lutz $P$ (1987) Energy partitioning in fish: the activity-related cost of osmoregulation in a euryhaline cichlid. J Exp Biol 128: 63-85.

34. Foskett JK, Schaffer C (1982) The chloride cells: A definitive identification as the salt-secretory cell in teleost. Science $215:$ 164-166.

35. McCormick SD (1995) Hormonal control of gill Na+, K+-ATPase and chloride cell function. In: Cellular and Molecular Approaches to fish ionic regulation. Fish. Academic Press, London.

36. Hibiya T (1983) An atlas of fish histology. Normal and pathology features. Koddasha LTD. Tokyo. 